\title{
Going to College: The Experiences of a Young Woman With Down Syndrome
}

\author{
Lee B. Hamill
}

\begin{abstract}
In this qualitative study the college experience of an individual with Down syndrome was examined. The student audited two academic courses and participated in various nonacademic campus activities. The investigation yielded multiple themes within the following areas of importance: (a) the meaning of going to college, (b) the development and meaning of college friendships, (c) negotiation of the academic program, and (d) enrichment of the lives of those involved. The findings showed benefits to both the student's personal and professional development. The struggles and successes within each area of importance are described and implications for each are discussed.
\end{abstract}

As more students with disabilities have been included in pre- $\mathrm{K}$ through high school general education programs, they are becoming increasingly interested in also having a college or university experience (Page \& Chadsey-Rusch, 1995; Smith, 1998). (The terms college and university are used interchangeably to refer to institutions of higher education that offer 4-year baccalaureate programs.) A relatively large percentage of students with disorders such as language and learning disabilities as well as visual, hearing, orthopedic, or other health impairments pursue academic coursework in postsecondary education programs (Turnbull, Turnbull, Shank, \& Leal, 1999). Students with cognitive disabilities are found far less frequently among the students with disabilities enrolled in academic programs on college campuses. Often, those students and their families do not consider college an option (Page \& Chadsey-Rusch, 1995). In those instances when students with cognitive disabilities are included, they often reside or work on campus but are enrolled in a separate life skills training program (Goldstein, 1993).

The professional literature contains few examples of students with cognitive disabilities who participate in academic programs in either community colleges (institutions of higher education offering 2 year programs that provide training in specific skill areas and/or academic programs) or 4-year institu- tions. In one noteworthy exception, two students with mental retardation participated in computer and fitness courses at a community college (Page \& Chadsey-Rusch, 1995). The experience gave them complimentary prestige, increased their self-esteem, and was a source of pride for their parents. However, even though the students' interpersonal and social lives were positively affected, going to college did not appear to help them define or prepare for future careers.

In a second example, students with moderate to severe disabilities participated in a project focused on providing them inclusive experiences with college life (Deubner, 1993). The students had peer mentors and audited academic classes rather than take them for credit because they were not able to successfully complete the stringent entrance testing or course requirements. The students found the classes very difficult and needed help with homework, papers, and tests. The peer mentors struggled with how much or little to do for the students.

In a third instance, a small college in Kentucky also developed a program to give students with moderate to severe disabilities the opportunity to audit courses and participate in school activities (Hall, Kleinert, \& Kearns, 2000). The students made friends and received support from their typical peers in class and during other activities on campus. The faculty also was responsive and attended to the individual needs of the students. 
My purpose in this investigation was to learn about the experiences of Megan (a pseudonym), an individual with Down syndrome, who had recently participated in the academic program at another university in the Midwest. Being able to attend college was an important milestone in Megan's life. She was determined to achieve two goals: (a) to live on her own and (b) to go to college. This study was designed to explore Megan's experience at the university.

\section{Method}

I used qualitative methods to collect and analyze information about Megan's college experience from multiple perspectives: those of Megan and the faculty and students who interacted with her on campus (Bogdan \& Biklen, 1992). Observations and interviews with these participants provided a picture of the experience and allowed me to interpret and, hopefully, give readers a rich understanding of the complexities of the interactions (Eisner, 1998).

\section{Participants}

The participants were Megan, a 26-year-old woman with Down syndrome, 7 other students, and 3 members of the faculty/staff. They were purposively chosen because they could give important insight into this rare event (Bogdan \& Biklen, 1992).

Megan was identified with cognitive disabilities on her Individualized Educational Plans (IEPs) and had gone through school almost entirely in special education classes, although she was able to take a few general education classes before finishing high school. She now lived on her own in a small apartment. She shopped, cooked, and cleaned for herself but did receive some help from her father in managing her finances. I found Megan to be an outgoing person who had excellent social skills. She smiled and listened attentively to others, although she occasionally became a bit confused about the specifics in what others said to her. For example, she sometimes looked quizzically at the person but waited patiently for him or her to stop speaking and then politely asked what the person was trying to say. Megan was an experienced self-advocate who spoke nationally on that issue. She gave speeches about how it felt to have Down syndrome. She talked about how others often treat individuals who have disabilities similar to hers as well as about what they can and should do to treat these people with re- spect. Megan worked as co-editor of a newsletter for individuals with disabilities and had authored opinion pieces, information articles, and interviews.

The other student participants included 2 study buddies, 3 other classmates, and 2 acquaintances who knew Megan in campus settings outside of class. In each course, one of Megan's classmates volunteered to be her "study buddy." An undergraduate special education major was her study buddy in the first course Megan took. She was eager to participate and kept the mornings after the class free to spend extra time with Megan. In her second course, Megan had a different study buddy, a biology major who was taking the course as an elective. Both study buddies were enrolled in an independent study while they worked with Megan. The first study buddy was supported and supervised by a special education faculty member through the independent study. The second study buddy received independent study credit and guidance from the course instructor as well as additional assistance if needed through the campus Learning Assistance Office. The study buddies supported Megan by explaining assignments and academic concepts that were difficult, sharing class notes, and encouraging Megan when she became overwhelmed or frustrated. The 3 classmates were a nontraditional female student (a nontraditional student refers to one who is older than the majority of classmates who enter colleges or universities immediately following high school), and two traditional students-one man and one woman (a traditional student refers to the majority of full-time students who have entered a college or university immediately after high school and have not left to pursue other interests before returning to finish their degrees.) Of the two acquaintance participants, both were men who were traditional students. Megan met and became friendly with one while eating lunch in the cafeteria and was in an extracurricular club on campus with the other.

The faculty/staff participants included the director of the Learning Assistance Office and the two faculty members who taught Megan. Both professors were full-time members of the Communication Arts Department at the university. One was a woman with more than 25 years teaching experience and the other, a man who had taught for more than 30 years. The director of the Learning Assistance Office organized Megan's program and arranged for her to audit classes. She also helped Me- 
gan, the student buddies, and faculty coordinate their activities with one another.

All the participants were fully informed about the purpose of the study. In addition, Megan, the professors, and the study buddies understood the research guidelines. Megan knew the study buddies wanted to learn about her college experiences as well as provide support. All participants were assured of confidentiality and could choose to withdraw from the study at any time. The student participants were further guaranteed that withdrawal from the study would not affect their grade or their continued enrollment in the course.

\section{Setting}

Megan was enrolled in a private 4-year liberal arts Jesuit university in the Midwest. Of the approximately 6,500 students enrolled in this urban university, about 3,500 were undergraduates. Eighty-six percent of the undergraduates were residential students; the other $14 \%$ were commuters like Megan. Megan participated in a "community project" program at the university with a nondegree status. This particular program afforded the opportunity for an interested student with disabilities who might not otherwise meet the university's entrance requirements to audit selected courses and have the tuition waived. The program was started by one of the university's vice-presidents who was active in the local Special Olympics. When Megan expressed an interest in going to college, he asked the director of Learning Assistance to facilitate her on-campus experience.

Megan audited two courses in the Communication Arts Department during consecutive fall semesters. Her work schedule and the lack of available appropriate courses with interested faculty precluded her participation in classes during the intervening term.

The first course Megan audited, Interpersonal Communication, addressed a set of competencies that can help to develop and maintain effective interpersonal relationships with family, friends, and co-workers. The second course, Presentational Speaking, focused on the students giving presentations on a variety of topics (e.g., introductory, informational, advocacy, persuasive, and goal attainment). Both classes were small, with 25 students enrolled in the first course and 19 students in the second. While Megan was on campus, she frequently ate lunch after class in the student cafeteria and occasionally studied in the library.

\section{Data Collection}

Data collection took place during a brief period of about one week during the spring semester prior to Megan's enrollment in classes, throughout two fall semesters, and for about one week after each term ended. The study buddies and I observed Megan in a variety of academic and social activities on campus. I spent time with Megan in several settings, including the school cafeteria, the library, the Learning Assistance Office, and a local restaurant. To avoid disturbing the natural environment, I did not attend classes with her. Also, to maintain the naturalistic nature of ethnography, the professors treated the study buddies as if they were enrolled students. They blended into the class by participating in all the in-class activities. Observations of Megan's engagement in academic work and her social interactions with other students and faculty were documented in fieldnotes.

As part of the independent study requirements, the study buddies kept field logs to describe their interactions with Megan as well as the interactions Megan had with classmates, the instructors, and the course material. To investigate the classroom environment, I subsequently analyzed the study buddies' field logs. In addition, I met with them frequently and kept fieldnotes of those conversations. I also kept fieldnotes on interactions and conversations with the other students, the director of Learning Assistance, and the faculty members who taught Megan. Fieldnotes were written on site in abbreviated form. They were reread and expanded, usually within 30 minutes of leaving the site (Spradley, 1980). Once I entered them in the computer, my fieldnotes and those I collected from the study buddies comprised over 250 pages of observational data.

As noted previously, my observations of Megan occurred in the cafeteria, the Learning Assistance Office, and the library or outside the academic buildings. The study buddies observed Megan's interactions during the 1 hour and 15 minute class period twice a week over the semester. They also occasionally observed and recorded interactions Megan had in other settings. For example, the first study buddy frequently met Megan during lunch in the student cafeteria, and the second study buddy visited Megan's apartment. The length and location of the participant observations are listed in Table 1.

Megan's feelings about her college experiences, as well as the perceptions of the other participants, were recorded during interviews. All the partici- 
Table 1 Incidence of Data Collection

\begin{tabular}{|c|c|c|c|c|c|c|}
\hline \multirow[b]{2}{*}{ Participant } & \multicolumn{3}{|c|}{ Observations ${ }^{\mathrm{a}}$} & \multicolumn{3}{|c|}{ Interviews $^{\mathrm{a}}$} \\
\hline & No. & $\begin{array}{l}\text { Approx. } \\
\text { length }\end{array}$ & Location & No. & $\begin{array}{l}\text { Approx. } \\
\text { length }\end{array}$ & Location \\
\hline \multirow[t]{5}{*}{ Megan } & 6 & $20-40$ & Cafeteria & 2 & 60 & Local restaurant \\
\hline & 1 & 45 & $\begin{array}{l}\text { Learning Assistance Of- } \\
\text { fice }\end{array}$ & 5 & $10-15$ & Cafeteria \\
\hline & & & & 1 & 75 & $\begin{array}{l}\text { Down Syndrome Socie- } \\
\text { ty office }\end{array}$ \\
\hline & 7 & $5-10$ & $\begin{array}{l}\text { Library, student union, } \\
\text { and campus green }\end{array}$ & & & \\
\hline & 46 & 75 & Classroom & & & \\
\hline \multirow{2}{*}{$\begin{array}{l}\text { Additional fieldnotes } \\
\text { from study buddies }\end{array}$} & 17 & $10-15$ & Cafeteria & & & \\
\hline & 1 & 15 & Megan's apartment & & & \\
\hline \multirow[t]{2}{*}{ Faculty member 1} & & & & 1 & 90 & Cafeteria \\
\hline & & & & 1 & 10 & By phone \\
\hline \multirow{2}{*}{ Faculty member 2} & & & & 1 & 90 & Faculty dining hall \\
\hline & & & & 1 & 5 & By phone \\
\hline $\begin{array}{l}\text { Director of Learning } \\
\text { Assistance }\end{array}$ & & & & 5 & $10-15$ & By phone \\
\hline \multirow[t]{2}{*}{ Study buddy 1} & & & & 2 & 30 & Office of researcher \\
\hline & & & & 5 & 15 & \\
\hline \multirow[t]{2}{*}{ Study buddy 2} & & & & 1 & 90 & Cafeteria \\
\hline & & & & 2 & 10 & By phone \\
\hline $\begin{array}{l}\text { Five other students } \\
\text { (each) }\end{array}$ & & & & 1 & 30 & Classroom/Cafeteria \\
\hline
\end{tabular}

an minutes.

pants were formally interviewed on one or more occasions and, whenever possible, they also were engaged in casual conversations (Jacob, 1987). Open-ended questions were used to encourage the participants to identify and define topics they found important relative to Megan (Patton, 1980). The questions were designed to allow participants to describe their experiences related to the investigation without interfering in the direction those responses might take (Seidman, 1991). Examples of the questions asked of the different participants are as follows:

Questions for Megan:

1. Why did you want to come to college? What do you like best about college?

2. What can you tell me about your class? What kinds of things do you do in class?

3. How is class going? What have you been learning that's new?
4. What can you tell me about your teacher? What can you tell me about your classmates?

5. What things have helped you in class?

6. What other kinds of things do you do at school besides go to class?

7. What can you tell me about your study buddy?

8. What kinds of things do you do when you are not at school? How has your class made a difference in your life outside of school?

9. What things do you think could be different at school?

10. Can you think of anything else you want to tell me?

Questions for Professors:

1. What can you tell me about your experiences with Megan in class? What was it like having Megan in your classroom?

2. Can you give me some examples of the kinds of things you have being doing in class?

3. What do you think about the interactions between Megan and the other classmates? What kinds of informal interactions do you remember seeing? What kinds of things do you remember the students saying? 
4. It's very clear you see this as a positive experience. Can you tell me if you see any downside?

5. What else seems important to you?

Questions for Study Buddies:

1. Can you tell me about your experiences as a study buddy?

2. What kinds of things did you do with Megan?

3. Is there anything else you would like to talk about?

Questions for the Other Students in her Classes:

1. What can you tell me about the people in your class? What can you tell me about Megan?

2. What is it like in the cafeteria at lunch? How do people get together to eat? How did you come to eat with Megan? What can you tell me about Megan?

3. Is there anything else you want to share?

Questions for Other Students:

1. How do you know Megan?

2. Would you describe to me how your experience in class has been so far? Can you tell me about any other interactions you have had with Megan besides in the classroom?

3. What can you tell me about your interactions/conversations with her? In class? In the cafeteria?

4. What else would you like to say about your experiences with Megan?

Most interviews were tape-recorded and transcribed. On the few occasions when a taperecorder was not used, hand-written notes were taken. Megan was interviewed at the end of each course as well as occasionally during the time that she was taking the courses. She also participated in a followup interview to check the veracity of the data and resolve questions that arose in the analysis. Each faculty member also was interviewed once at the end of the course as well as informally by phone during the term. The director of Learning Assistance was interviewed informally during several phone conversations. Relevant information gleaned from those informal conversations was logged in the fieldnotes. The study buddies were interviewed individually over several different meetings while they were working with Megan. Each of the other student participants was interviewed once. The length and location of the participant interviews are listed in Table 1.

\section{Data Analysis}

Once all the data were collected, the fieldnotes and interviews were analyzed. To facilitate the development of a contextualized description of Megan's college experience, I repeatedly compared the fieldnotes and interview transcriptions to find patterns and identify issues of importance (Stewart,
1998). A computer was used to maintain and code the data with an automatic indexing system of category tags (Pfaaffenberger, 1988). When a topic of importance was identified in the fieldnotes or in an interview transcription, that passage was tagged with the appropriate identifier, such as inclusion. It was then copied with reference to its original location in the data into a separated file with all other identified inclusion passages. The coded data were organized into the categories that participants had repeatedly identified to develop emerging themes. To some extent, cross-referencing of the different participant comments provided member checks that established the validity of each emerging theme and maintained consistency across the different participants (Lincoln \& Guba, 1985; McMillan \& Schumacher, 1997). To illustrate, a theme such as "having friends" was considered a commonality across perspectives when Megan, her study buddies, and the professors all talked about Megan's interest in interacting with other college students. However, many of the topics of interest that emerged from the data were unique to Megan. Her experience was somewhat different than those of her classmates, but because her experience was the focus of the investigation, certain topics identified by Megan were included when the other participants remained silent. For example, Megan was the only student auditing the courses, so her perceptions of issues such as homework and testing were unique. Any topic about which Megan initiated comments on at least two separate occasions was considered important and contributed to the richness of understanding. Those unique data were then categorized into emerging themes and incorporated with the composites. The interpretation of the participants' combined individual and composite perceptions was integrated with the observations and organized into major themes and subthemes to give a detailed portrait of Megan's participation in an academic college program and provide insight into its meaning for her and the other participants (Geertz, 1973).

\section{Findings}

The investigation yielded four major themes: (a) going to college: realizing the dream, (b) having friends, (c) negotiating the academic program, and (d) everybody benefits. The first theme addressed the importance of having a college experience to Megan and her family; the second was focused on 
the social aspect of Megan's college experience. The third theme was a description of Megan's interactions with the academic work; and the final theme concerned the quality of the learning experience for all the participants. Each major theme was further organized into subthemes that focus on specific points within that topic. Table 2 shows the complete list of major themes and subthemes.

\section{Going to College: Realizing the Dream}

Going to college was extremely important to Megan. She met with university personnel before the semester began so she could become familiar with the school and learn what was expected of her. Several times during the initial meeting to set up her program, Megan said, "I'm finally realizing my biggest dream. ... to go to college." Although she was excited as she prepared to begin her first semester at college, she was a bit worried. The initial meeting also served to help alleviate those fears. Megan brought a prewritten list of concerns about dealing with college to the planning meeting, which took place in the Learning Assistance Office:

1. How do I get from the bus to class?

2. I'm not really sure how to use my ID card.

3. What books do I need to buy and where do I get them?

4. Where is [the professor's] office and telephone?

5. Is there going to be taking tests like other students? Am I going to get grades?

6. What should I do if I get confused or lost?

7. In a lot of colleges, kids are always drinking pop or eating. Is that ok for here, too?

8. What days are there no school? Are they just holidays?

9. Are there any social events that are happening that I should go to?

10. I don't know how to use the computers at [the college] for e-mail.

Megan's concerns were addressed and answered at the meeting by the director of the Learning Assistance Office and the study buddy for the first course. For example, the director told Megan that there might be tests and grades to tell her how she was doing. The study buddy explained how she would help when Megan had difficulty with the coursework and told Megan how to get an e-mail account on campus. She explained what a syllabus was and gave Megan advice about what would be on it. She also suggested Megan might want to join a club on campus.

Being independent like her sisters. Megan said she wanted to be like her two sisters who both went to college. As she remarked when she was preparing to begin her first college course,

I had two dreams. I wanted to go to college and to be independent away from home since I always lived there my whole life since I was 23 . I was with my parents and my parents were always smothering me and the family smothered me. I have my first apartment that I've been living in for 5 months. Now I want to go to college.

Megan described this desire to go to college on many different occasions and, once she started participating, she frequently expressed how proud she was of being in school. For example, as she finished her first course she commented, "People have got to remember that school is a part of my life. Now that I'm in college, it's important to me. I need to learn something to help me work [in a] professional way."

Many of the participants also reported that Megan told them about her strong interest in going to college. The director of the Learning Assistance Office noted that she talked about her sisters being in college and her parents meeting in college. One of the students who ate lunch in the cafeteria with Megan reported, "She says it is difficult but [she is] excited about being here." Megan's professors commented about how important being at college was to her. One of her professors noted, "She talks very

Table 2 Major Themes With Subthemes

\begin{tabular}{ll}
\hline Major themes & \multicolumn{1}{c}{ Subthemes } \\
\hline Going to college: realizing the dream & $\begin{array}{c}\text { Being independent like her sisters; participating like any other } \\
\text { student } \\
\text { Fiendships with other students; struggles with relationships }\end{array}$ \\
Having friends & $\begin{array}{l}\text { Participating fully; individualized participation; managing the } \\
\text { coursework; working hard to achieve; accessing supports; } \\
\text { degotiating the academic program } \\
\text { Everybody benefits } \\
\text { Personally meaningful; personal and professional benefits; rele- } \\
\text { vance beyond school }\end{array}$ \\
\hline
\end{tabular}


much about goal setting and that this has been a goal of hers. She talks about herself as a college girl in her writings."

Participating like any other student. Megan's classmates appreciated her presence in college and praised her participation in class. One of her classmates noted, "I think it's wonderful that she's on her own and that she can do the things that she does." Her second study buddy agreed, "She was well integrated into the class. She was just another member of the class." Megan's family also was thrilled that Megan was going to college, which mirrored the feelings of other similar families (Page $\&$ Chadsey-Rusch, 1995). To illustrate, one of her professors reported that on one occasion he received a long distance phone call from Megan's father to clarify an assignment. That same professor felt the college experience added to Megan's selfesteem. He said, "I think she felt very good about herself - that she was going to college. I think that it fulfills a kind of personal goal of hers. I think it's important to her to take the class and just be in the environment."

Still, Megan wanted to do more than just be in the college environment. Although she was auditing classes, she felt she should receive credit for her efforts. Some of her classmates agreed. The first study buddy said, "Megan was excellent and could have taken the class for a grade. Megan was always a step ahead [prepared for class]." Those sentiments were confirmed by another classmate who said, "It's not fair. Megan is excellent. She's doing the work." The study buddy agreed that Megan should be enrolled for credit. However, like other students with cognitive disabilities, Megan was auditing courses because she would not be able to pass the entrance tests requirements (Deubner, 1993). The study buddy recognized that fact when she noted with frustration,

Megan said she wouldn't be able to pass the entrance requirements to get credit for the course. I don't think it's fair. She put in the same dedication and effort as everyone else but still she couldn't get credit for the course.

The study buddy even suggested ways to make it possible for Megan to receive credit for her work. "I think they should have a special test for people like Megan so they can have the same opportunities and they can really take classes."

\section{Having Friends}

One of Megan's major reasons for going to college was her desire to have friends. Although the professors noticed Megan's hesitancy in socializing with her classmates, they observed students approaching and interacting with Megan. Her first professor commented, "A couple of the people engage her in conversation. She does not initiate conversation with other people." That professor speculated that students were attracted to Megan because she was "always smiling." Her second professor added,

I think the students were very supportive and she seemed to be very much in the middle of the group. In fact, another student [not the study buddy] helped her with Power Point. ... spent an afternoon with her.

Friendships with other students. The other students also noticed examples of friendships developing between Megan and other students at the college. Both of Megan's study buddies felt they had developed real friendships with her. The first study buddy was very positive about her relationship with Megan. She said, "I can actually say we were friends." The second study buddy reported exchanging phone numbers and addresses with Megan. She visited Megan's apartment, and they shared personal information with each other. The study buddies also reported that Megan became friends with other students on campus. For instance, she struck up a friendship with another student in the class, and they began e-mailing each other. Her first professor observed that a nontraditional student and a young woman in the class engaged Megan regularly in conversations.

Still, although her classmates appeared comfortable with Megan's presence in the room, they did not always include her in their informal interactions. One student remarked, "I haven't observed any negative reactions. She is not included in conversations though. Sometimes this is because people don't know her or because they talk about what they were doing that day."

One of the study buddies noted that Megan was anxious to participate in extracurricular activities. She said Megan told her she liked to go out and see her friends at the Natural Ties club meetings on campus (Hughes, 1994). In fact, Megan was a member of the Natural Ties group at the school. (Natural Ties is a student organization on many college and university campuses that brings peers with and without disabilities together to provide social connections and natural supports.) Several of the other student participants also noted Megan's eagerness to participate in typical college activities outside of 
class. For example, one student who only knew Megan from the student cafeteria said, "I sit with her a lot at lunch. The first time I ate by myself and Megan came up to me. She said, 'Hi, I am Megan. You look like you need someone to sit with.' Since then, I have eaten lunch with her several times with a group of friends." Another cafeteria pal noted,

Sometimes she would come right out and say that she likes it when people sit next to [her]. She wants to have someone to sit down with in the café. She is eager to get to know people. She is very open and honest about her feelings and what she wants.

Struggles with relationships. Although others noticed social interactions taking place and Megan repeatedly talked about how important it was to have friends, Megan frequently said that she felt lonely. This was somewhat inconsistent with the findings reported in other studies (Hall et al., 2000; Page \& Chadsey-Rusch, 1995). To illustrate Megan's social concerns, shortly after she began taking classes, Megan wrote a letter to the officers in one of the student clubs on campus. In it she said,

All I want is to just be a part of this university. I need more friends to talk to and hang out with. I can't tell my family that I am a part of this university now and show them its okay. I guess what I really need is just getting a chance to be involved.

The letter suggests that Megan recognized the importance of participating in activities outside of the classroom. She began to interact with students outside of class as her first semester progressed. For example, the student cafeteria sometimes provided a better opportunity than the classroom for Megan to develop friendships. She noted that the other students in her class did not always talk to her, particularly outside of class. As she reported, "I made friends through other things. Some of them are runners. I just sat down with them [in the cafeteria] and started talking about my sister because she's a runner for her college and now they always like sitting with me."

\section{Negotiating the Academic Program}

Megan struggled to navigate successfully through the academic coursework in college. She wanted to participate in the same way other students did, yet she sometimes had difficulty understanding the instructional procedures and specific concepts taught in her courses.

Participating fully. Megan wanted to participate fully in her classes, and her professors acknowledged her efforts. Her first professor noted, "She copies whatever is on the board into her notebook. She fully participates if there are small group discussions." The professor noted, however, that Megan liked to sit against the wall in the class and did not contribute during large group activities. Megan's classmates also noticed her difficulty initiating interactions in class, particularly in large group situations. One of her classmates reported, "Megan really didn't communicate a whole lot in the class. I think her style was more to observe and that's how she got things out of it." Another classmate added, "[Megan] is very quiet. [She] very seldom ever says anything unless she is asked to. She has to be on the receiving end of an initiation." During the first semester, the professor encouraged Megan to make some adjustments so she would be more involved in class activities. When Megan was invited into the group, the professor noticed Megan's body language changed, and she seemed more energized. Over time, Megan became more comfortable participating in class. She interacted well with her classmates when she participated in small group discussions. As her first study buddy observed, "When she became an active participant and suggested the question to discuss, the group [was] responsive." By the time she took the second course, her professor reported, "Megan sat up front on the left side in the first seat. She was not shy. She was a very obviously friendly, cooperative individual."

Individualized participation. Megan worked hard and was successful in many ways. The professor in her first course said, "She shared a speech that she delivers [as part of her job as a public speaker on self-advocacy]. It fit perfectly into stereotyping, and the class was very responsive to her. She did a nice job." The second professor also allowed Megan to use her own material in class presentations. That way, she could speak about things she did rather than try to strictly follow the assigned topics. He also noted that sometimes she went even further and did a very good job of designing something new.

Although her professors thought she integrated well in the classroom, Megan sometimes felt separated from the rest of the students in the class. For example, she audited courses whereas the other students took them for credit. Megan was not satisfied with this format, although it was typical of community projects like the one in which Megan was participating (Deubner, 1993; Hall et al., 2000). She told her second study buddy she was upset because she would not actually get credit for her ef- 
forts. In addition, she was excluded from getting grades for the work she did. She commented,

I know I'm auditing and all that, but when I took my test all I got was this note and talking over how I did. I thought in a way when I take those tests that I would be able to at least get some kind of a grade so I know how I did.

Her first study buddy told her comments were most important and not to worry about the letter grade.

Managing the coursework. Learning to manage the coursework presented challenges for Megan. She sometimes seemed confused about what was going on in the room and what she should do. The first study buddy noted, "[Sometimes the professor] talked too fast for Megan." In addition, she did not always understand how to deal with the information given in class. For example, her study buddy observed, "Megan kept looking at the notes of the girl sitting next to her. She had her notebook open [but] she was not writing anything down." Megan frequently relied on her study buddies for help so she could participate successfully in the academic work. For example, the study buddy noted, "I asked her if she had any questions about what took place in class. She said she did not know when to write stuff down." Sometimes, she was hesitant to ask for help in front of other students. The study buddy reported, "After class, she stood to the side and waited for me. She told me that she didn't understand the stuff we were doing in class." Megan also acknowledged her tentativeness in class, "I don't always ask the teachers. I get kinda shy. I don't like doing it in front of everyone 'cause they just look at me weird or funny even though I'm really good at it." However, she showed resourcefulness in accessing help from her professors at other times. For example, she noted, "I always ask before class, 'What are we going to do today? What are we actually talking about?' I learn that way and, before everyone gets in, I start writing down notes on what she [the professor] is putting on the chalkboard." She also communicated with her professors through e-mail.

Working hard to achieve. Megan was diligent in her efforts and learned how to study to improve her work. For example, she noted,

I think I'm pretty good at listening, but I don't always pick it up the right way. At first I wasn't using a study guide. I'd forgotten that everything that is being described in the test is in that book.

Once Megan learned how to study more effectively and began to understand the material, she really enjoyed her college classes. After she finished her first course, Megan sent an e-mail message about her experience to the director of the Learning Assistance Office. She wrote, "My final for my test is now done. My studying went really good. I feel really good about it." Although she enjoyed both courses, Megan found the second one easier to manage than the first. In the second course, presentations replaced tests, and packets with step-by-step instructions were used instead of a textbook. Megan had struggled with the textbook in the first course. As she explained,

[The first class] had a textbook. It wasn't in people first language because the words are big. I would get through the words 'cause my mom kinda taught me to try to sound each word out but I never knew what the words meant.

The second study buddy felt Megan managed the coursework as well as the other students in the class. She reported, "We set goals for ourselves. As long as you tried, you were OK." Megan confirmed setting her own goals and working to attain them. She said she wanted to develop better relationships with co-workers, and role-playing activities in class helped her learn new patterns of interaction in different relationships. She acknowledged using her new skills to resolve a conflict with one of her coworkers. She even noted with pride that they were still friends.

Megan also found test-taking frustrating and the concepts covered in class hard to grasp. Her difficulties were similar to those experienced by the students in the Deubner study (1993). In her first course, Megan struggled but was eager to take the tests like the other students. When a friend from the cafeteria asked her how her class was going, Megan said it was kind of hard, and she did not know some of the material. She wondered whether someone could help her with the tests. Her professor noted, "She wants to take the tests. She took the first test at the Learning Assistance Office. She took the second one in the classroom." Megan wanted to stay in the room with her classmates rather than go the Learning Assistance Office to take her tests because she felt taking her tests in a different room was boring and lonely.

Accessing supports. Megan frequently relied on her study buddies for support to help her gauge her success at school and find ways to improve her efforts. For example, she asked them to help her understand what material she should take notes on and study. They showed her how to take notes in outline form and suggested making flashcards as a 
study aid. However, like the peer mentors in the Deubner study (1993), the study buddies sometimes felt uncomfortable about the level of support they gave Megan. They did not always feel competent to help when Megan had difficulty understanding a particular concept, although the professors thought they gave the needed advice. Megan also received help from other classmates. For example, a classmate asked Megan if she wanted help using Power Point and assisted her with the presentation.

The professors observed that Megan had academic strengths in memorizing material and being a good rote responder. At the same time, they were somewhat uncomfortable with their inability to provide Megan with the support she needed to manage her courses. They sometimes relied on information from the study buddies. The first study buddy remarked that the professor asked whether her teaching was helping Megan learn the material. Like the faculty in the Hall et al. (2000) study, the professors also gave individualized support to Megan. For example, Megan periodically phoned them for help.

Dealing with the content. The professors recognized that Megan faced some difficulties, but they saw improvement in her ability to manage the information. One of the professors commented, "The part that I think was difficult and maybe impossible for her to achieve was to use notes [during her presentations]." The other professor also observed instances where Megan struggled. She once noted,

She didn't get today's exercise. It's clear to me she's not quite understanding. I didn't have time to teach her to do it. I don't know if she made something up or what, but she said to me, "I think I have done this wrong."

Megan was not the only one who struggled. For example, one professor noted that she had difficulty helping Megan understand how to do the written assignments. The other professor reported a difficulty both he and the study buddy experienced. He commented, "The hardest part was the scheduling problem, both for me and for the student who spent time with her." Both professors expressed a desire to have a personal connection with the Learning Assistance Office. The first professor had difficulty discussing written assignments with Megan because her work was below the typical standards for the class. She expressed her frustration when she remarked,

In retrospect, I probably would have benefited from a little coaching on expectations. I'm overprotective of her feelings, which is one of my demons. I want to answer [Megan's] questions but do it in a way that is honest yet encouraging.

The second professor suggested,

It's important to the success of a program like this that there's support for the professor; from someone who says 'call me if you have any problems.' [The Learning Assistance Office should] be more involved with the student who serves as a buddy.

Everybody Benefits

Megan's college experience was clearly positive and beneficial for all involved. Not only did Megan find the coursework meaningful, but the study buddies, the course instructors, her other classmates, and friends from the cafeteria all felt they were enriched by knowing Megan and learning about her life.

Personally meaningful. Megan felt she learned a lot in the two courses she took. In describing her first course, she reported, "Interpersonal relationships is like going in the inner self, talking about feelings of how you feel dealing with relationships between, not just a boyfriend and girlfriend, but relationships inside yourself and what those concepts were." In characterizing the second course, she said, "You're talking in front of a class and they videotape you doing your actual presentation on your own. You always have to have an open, a body, and a close in your speech."

Megan's classmates also found Megan's involvement in the class personally enriching. Her classmates observed that the classroom environment was comfortable and enjoyed getting to know Megan. As one student said, "She spoke to us about what she does with her disabilities and the job that she's doing here and being away from home being on her own. ... things of that nature." Another classmate said, "I think [her talks] were very inspiring. She had affected me insofar as saying, 'Hey, if you really want to do something, you can."' A third student observed "I thought it was great that she was in class. It was neat to have that experience, especially on days when she would share stuff!" That same student noted that "[Megan's] strong, determined, willing to talk about herself, and very positive."

Both professors also felt the other students in class benefited from having Megan as a classmate. The first professor pointed out,

The students in the class recognize that Megan has made a wonderful contribution. Her presence, her steadfastness, her delightful personality has enriched the group. She is an active listener. She doesn't offer too many of her own opinions or comments, but her willingness to be present has added a lot. 
The second professor said,

For the other students, I think it's good too. I think it was a great opportunity for other students to see her on a continual basis. She uses the word disability more that I thought she would. A lot of folks really learned a lot just from what she did talk about. I mean, it certainly breaks down some stereotypes that one might have.

In addition, the professors appreciated having Megan as a student. The first professor said, "If asked again I would participate. It has certainly been wonderful and pleasant."

Personal and professional benefits. Megan saw benefits in both her personal and professional life. She learned how to improve her interactions with friends and co-workers. She reported, "[I] learned how to deal with the relationships with your friends and co-workers and how to have good behavior. [I changed the way I] deal with relationships, especially co-workers." She often talked about her personal life in her class assignments. She reported, "I talked about my behavior skills from my parents' point of view, what my living skills are, what my nonverbal behaviors are [and] how honest I am." Both professors observed that she brought her own experiences into the classroom. Her first professor noted, "In her papers, she talks a lot about her inability to tell people what she feels, that she's afraid they're going to be mad at her." The second professor gave her quite a bit of autonomy in choosing the material she would discuss. In Presentational Speaking, Megan noted,

I picked [two of] my own presentations. The first one I did on People First, by telling them what it was about and trying to get them excited 'cause I'm [the state] president. And the other one I informed on was that great big bike ride across the state for healthy lifestyles, and telling them about the project.

Megan knew that she was enriching the lives of her classmates by teaching them about disability. She considered that meaningful, as her comments illustrate, "One neat thing that I got out of it was informing them. I brought something really neat into their life." Not only did Megan think her college experience was very meaningful, but her study buddies confirmed those feelings. Her second study buddy reported that going to college had increased Megan's self-esteem. This finding mirrored the experience of other students in similar programs (Page \& Chadsey-Rusch, 1995).

As students outside of class got to know Megan, they also were impressed with her capabilities. One student said, "Meeting Megan really changed my perceptions. In elementary school, individuals with disabilities were always put in different classes, so I always thought they were different." One of Megan's cafeteria buddies remarked that "I have never been around people with Downs. I am surprised at how well she functions."

Relevance beyond school. Finally, Megan's academic experience served a utilitarian function. Both courses stressed practical application as opposed to a theoretical focus. The first class dealt with issues such as conflict management, forming positive relationships, and nonverbal communication. It was interactive, with skill building exercises and small group discussion. The outside assignments included reflective papers and interviews. The second course had an emphasis on speaking effectively to a group. Megan began to use the techniques she had learned in class in her personal life. She noted, "I'm trying to use appropriate language now that I learned in class." She also was able to use what she learned in her professional interactions. She felt that she had been taught new techniques for speaking to groups. As she noted, "I'm trying to get a state-wide group going for people who are self-advocates because not a lot of people know what self-advocacy is. It's part of my job to talk to people. I do it all the time at work." She also planned to use the Power Point procedures she learned in class when she prepares future self-advocacy speeches. In this respect, Megan's experience was different from other students who had participated in a similar program (Page \& Chadsey-Rusch, 1995).

\section{Discussion}

Megan was excited about her classes and felt she had a positive experience. In fact, she expressed strong interest in taking future courses. She specifically noted a desire to enroll in acting or writing courses. The other student and faculty participants also were enthusiastic and repeatedly described their experiences as positive both for themselves and for Megan.

The first major theme, going to college: realizing the dream, identified Megan's feelings of pride about her independent life style as well as her strong desire to be a college student like her sisters. Megan saw the college experience as a symbol of her adulthood. She wanted to do the same things she saw others her age do and that meant going to college. Although she showed some initial apprehension when she arrived on campus, her concerns quickly disappeared when she met her first study 
buddy. The support she received from study buddies and professors coupled with the social interactions she had with other students in classes, in the cafeteria, and at club meetings all contributed to her being able to realize her dream of being a college student. Once she learned how to effectively study the course material and got involved with other students on campus, the only lingering frustration she had was that (unlike her classmates), she did not receive letter grades and regular course credit.

The second major theme, having friends, highlighted Megan's intense interest in developing friendships through school. She wanted to be involved and was particularly interested in the social aspects of college. The study buddies reported that Megan interacted appropriately and appeared confident in class as well as in other university environments, such as the student cafeteria. Still, Megan sometimes struggled with feelings of loneliness in her desire to be part of the social life on campus. It was somewhat difficult for her to get involved because many of the activities took place through the residence halls in the evenings and on weekends. However, Megan did find ways to participate. She actively took part in the Natural Ties Club and regularly ate lunch with the friends she had made at school, which helped her feel part of the nonacademic experience.

Negotiating the academic program was the third major theme found in the data. It focused on Megan's academic experience and revealed the extent to which her experience mirrored that of her classmates. The academic aspects of Megan's experience had mixed results. She sometimes expressed confusion about what the professor was teaching. She frequently struggled with what to take notes on, and she watched the professor, her study buddy, or students sitting near her for direction. However, she became more familiar with class expectations as her first academic semester progressed. She learned several strategies that helped her manage her acquisition of the academic content, such as using a commercial study guide and seeking support from a study buddy outside of class to help her better understand the course material. Study buddies provided valuable guidance in helping Megan learn how to take notes and providing her with a copy of their own notes so she could concentrate on listening during class. By the time she took her second course, Megan integrated well into classroom activities. She understood what was expected and executed her responsibilities with greater ease. The structure of the second course also provided relief from test-taking, which had caused Megan the greatest difficulty in managing the first course.

The final major theme, everybody benefits, highlighted the discovery that a win-win situation resulted when Megan participated in the college experience. It showed the effect Megan had on the lives of those involved in her college experience and identified connections between her coursework and her career. Her study buddies, classmates, and professors reported that their lives were made richer as a result of the personal stories Megan shared in class. Megan also made meaningful connections with her personal and professional life in both courses, which she felt contributed to her understanding of her relationships with friends and coworkers. She also developed new confidence in speaking publicly, which she believed was a result of the skills she learned and practiced in the university classroom.

Megan and other students with cognitive disabilities, such as those who have participated in similar programs at other universities, have begun to challenge the established belief system that at least average cognitive ability is the required prerequisite for being part of the college community (Deubner, 1993; Hall, Kleinert, \& Kearns, 2000). Whether a student with cognitive disabilities can qualify academically for entrance into a university may not be as important as providing an opportunity for the student to have a college experience. Regardless of the extent to which a student is included in the traditional program, colleges and universities need to find creative ways to allow this new category of "nontraditional" student to participate.

One factor that contributed to the success of this program was the small class size. Also, Megan's courses were performance-based, which helped her make connections with much of what she did outside of school. Another benefit was Megan's inclusion in college life beyond the academic courses in activities such as using the library, eating in the school cafeteria, participating in extracurricular clubs, and having e-mail access. Finally, the support Megan received helped make her academic experience positive. For instance, she used a commercial study guide, received help from classmates with note-taking and using computer software, got assistance in learning course concepts during and after class from study buddies, interacted with faculty outside of class by phone and e-mail, and took ad- 
vice from the director of the Learning Assistance Office.

A barrier to Megan in feeling she was part of the full college experience was not receiving grades, which would have allowed her to determine how she was doing in the classes. Megan had expected grades for the tests and courses because the director of the Learning Assistance Office had mentioned the possibility during the planning meeting before Megan began her classes. Tests present another significant barrier to Megan's success in future classes. The Presentational Speaking course played to Megan's strengths because it was a performance class rather than being based on reading and test-taking. Other life experiences courses, such as group dynamics or speech, would likely be good choices for Megan if she continues taking classes in the future.

Academic expectations for students should be identified and agreed upon by all the relevant parties before the student is told what to expect. Learning Assistance Office personnel and course instructors should collaborate to determine what modifications are appropriate as well as how to accurately measure the student's progress. Modifications can be made that may facilitate students with cognitive disabilities to realize their college dreams, such as identifying possible courses and faculty who might resonate with the student as well as modifying requirements for entrance and participation in the academic program. The following are examples of possible modifications:

1. Learning Assistance Office training for study buddies/faculty

2. Learning Assistance Office provides periodic support for study buddies/faculty

3. Predetermined schedule for student meetings with faculty/ study buddies

4. Modifications to entrance requirements

5. Modifications to course requirements

6. Adjustment to test scoring

7. Modified grading procedures

8. Alternative methods of assessment

This study and other similar studies have illuminated the fact that university personnel are being called upon to provide services to students with disabilities (Dukes \& Shaw, 1998). Although this study cannot provide a template for the college experiences of all students with disabilities, the understanding gained through investigating Megan's experience can offer insights that may be helpful to others. Knowledge about the perceived experiences of individuals with disabilities can inform university administrators and faculty members who may choose to become involved in or facilitate similar opportunities for other young people with disabilities.

In the future, college and university personnel may want to develop "community projects," such as the one described here. In planning this kind of program, the school's Learning Assistance Office might develop a brochure to answer frequently asked questions similar to those Megan listed. Offering the opportunity to do an independent study is not only a good way to compensate the study buddy but also provides an excellent vehicle for learning about diversity. Learning assistance personnel also can support study buddies and the participating faculty by helping to determine specific requirements for independent study credit and overseeing the completion of those requirements. It also might be helpful for the Learning Assistance Office to provide training for study buddies in how to give effective guidance to the student and for faculty in how to devise appropriate modifications and alternative assessments. Finally, the Learning Assistance Office can provide periodic support for both study buddies and faculty. Before classes begin, learning assistance personnel can meet with the study buddies and the relevant course instructors to review their responsibilities and address individual concerns. They also can schedule periodic meetings with the student, the study buddy, and the professor to address concerns that arise during the semester.

\section{References}

Bogdan, R. C., \& Biklen, S. K. (1992). Qualitative research for education: An introduction to theory and methods (2nd ed.). Boston: Allyn \& Bacon.

Deubner, S. (1993). Full stream: Empowerment for life. Paper presented at the annual convention of the Council for Exceptional Children, San Antonio. (ERIC Document Reproduction Service No. ED 380 919)

Dukes, L. L., III, \& Shaw, S. F. (1998). Not just CHILDREN anymore: Personnel preparation regarding postsecondary education for adults with disabilities. Teacher Education and Special Education, 21, 205-213.

Eisner, E. W. (1998). The enlightened eye: Qualitative inquiry and the enhancement of educational practice. New York: Macmillan.

Geertz, C. (1973). Thick description: Toward an interpretive theory of culture. In C. Geertz (Ed.), The interpretation of cultures: Selected es- 
says by Clifford Geertz (pp. 3-32). New York: Basic Books.

Goldstein, M. T. (1993). LINK: A campus-based transition program for non-college bound youth with mild disabilities. Career Development for Exceptional Individuals, 16, 75-85.

Hall, M., Kleinert, H. L., \& Kearns, J. F. (2000). Going to college!: Postsecondary programs for students with moderate and severe disabilities. Teaching Exceptional Children, 32(3), 58-65.

Hughes, P. (1994). The Tieline, 3, 1-6. (Available from Natural Ties Inc., 520 Davis St., Suite 206, Evanston, IL, 60201)

Jacob, E. (1987). Qualitative research traditions: A review. Review of Educational Research, 57, 150.

Lincoln, Y. S., \& Guba, E. G. (1985). Naturalistic inquiry. Newbury Park, CA: Sage.

McMillan, J. H., \& Schumacher, S. (1997). Research in education: A conceptual introduction (4th ed.). New York: Longman.

Page, B., \& Chadsey-Rusch, J. (1995). The community college experience for students with and without disabilities: A viable transition outcome? Career Development for Exceptional Individuals, 18(2), 85-96.

Patton, M. Q. (1980). Qualitative evaluation and research methods. Newbury Park, CA: Sage.

Pfaaffenberger, B. (1988). Microcomputer applications in qualitative research: Qualitative research methods (Vol. 14). Newbury Park, CA: Sage.

Seidman, I. E. (1991). Interviewing as qualitative research: A guide for researchers in education and the social sciences. New York: Teacher's College Press.

Smith, J. D. (1998). Inclusion: School for all students. Belmont, CA: Wadsworth.

Spradley, J. P. (1980). Participant observation. Fort Worth: Harcourt Brace Jovanovich.

Stewart, A. (1998). The ethnographer's method: Qualitative research methods (Vol. 46). Newbury Park, CA: Sage.

Turnbull, A., Turnbull, R., Shank, M., \& Leal, D. (1999). Exceptional lives: Special education in today's schools (2nd ed.). Upper Saddle, NJ: Merrill.

Received 2/13/01, first decision 8/27/01, accepted 8/8/02.

Editor-in-charge: Chris Kliewer

Author:

Lee B. Hamill, PhD, Associate Professor, Special Education Program, 3800 Victory Parkway, Xavier University, Cincinnati, OH 45207-6613. E-mail: Hamill@xavier.edu. 